\title{
Examining Children's Questions and Parents' Responses about Covid-19 Pandemic in Turkey
}

\author{
Burcu Ünlütabak ${ }^{1}$ İlayda Velioğlu ${ }^{2}$ \\ ${ }^{1}$ Nuh Naci Yazgan University, Department of Psychology \\ ${ }^{2}$ Kadir Has University, Department of Psychology
}

Correspondence concerning this submission should be addressed to Burcu Ünlütabak.

Nuh Naci Yazgan University

Kayseri, Turkey

Email: burcuunlutabak@gmail.com

ORCID ID: 0000-0002-1299-1177 


\section{Declarations}

Funding: The research reported here was supported by Nuh Naci Yazgan University Scientific Projects Support Program (Grant \#2020-SO-BP/1)

Conflicts of interest/Competing interests: The authors declare that there are no conflicts of interests to disclose.

Availability of data and material: The data files for this study is available on Open Science Framework https://osf.io/daf7b/?view only $=94 c 23 c f 8 d a f 146688 d 2 a 7 b c a 7 a a c 5 f 23$

Code availability: The R code files for this study are available on Open Science Framework at https://osf.io/daf7b/?view only $=94 c 23 c f 8 d a f 146688 d 2 a 7 b c a 7 a a c 5 f 23$

\section{Authors' contributions:}

Burcu Ünlütabak was responsible for the conceptualization of the study, funding acquisition, methodology, data collection, data curation, coding, data analysis, and interpretation, supervision, writing-original draft, writing-review \& editing

İlayda Velioğlu was responsible for the data curation, coding, data analysis, and interpretation, writing-original draft.

Ethics approval: All procedures performed in studies involving human participants were in accordance with the ethical standards of the institutional and/or national research committee and with the 1964 Helsinki declaration and its later amendments or comparable ethical standards. This article does not contain any studies with animals performed by any of the authors.

Consent to participate: Parents were informed about all aspects of the study and informed consent were obtained from all participants before the online survey began.

\section{Consent for publication: NA}

Acknowledgements: We appreciate all parents who participated in this study during the COVID-19 pandemic. We also thank undergraduate research assistants for their help in data coding. We especially thank Karl Rosengren, David Menendez and Graciela Trujillo-Hernandez for their support and insightful comments during the preparation of this manuscript. 


\begin{abstract}
:
COVID-19 pandemic has had a significant impact on both adults' and children's everyday lives. Conversations about biological processes such as viruses, illness, and health have started to occur more frequently in daily interactions. Although there are many guidelines for parents about how to talk to their children about the coronavirus, only a few studies have examined what children are curious about the coronavirus and how they make sense of the changes in their everyday lives. This study addresses this need by examining children's questions and parents' responses about the Covid-19 Pandemic in Turkey. Using an online survey, we asked 184 parents of 3- to 12-year-olds to report their children's questions about coronavirus and their answers to these questions. We analyzed children's questions and parents' responses using qualitative and quantitative analyses (Menendez et al., 2021). Children's questions were mainly about the nature of the virus (34\%), followed by lifestyle changes $(20 \%)$. Older children were more likely to ask about school/work and less likely to ask about lifestyle changes than younger children. Parents responded to children's questions by providing realistic explanations (48\%) and reassurance $(20 \%)$. Only $18 \%$ of children's questions were explanation-seeking "why" and "how" questions. Parents were more likely to provide explanations if children's questions were explanation-seeking. Family activities such as playing games and cooking were the most common coping strategies reported by parents (69.2\%). The findings have important implications for children's learning about the coronavirus and how adults can support children's learning and help them develop coping strategies in different sociocultural contexts.
\end{abstract}

Keywords: child question-asking behavior, parents' explanations, conceptual development, COVID-19 pandemic, sociocultural context 


\section{Examining Children's Questions and Parents' Responses about Covid-19 Pandemic in Turkey}

The COVID-19 pandemic has had an immediate and widespread impact on people's lives everywhere in the world, including young children. This impact is likely to be reflected in parent-child conversations, leading to an increase in talk about biological processes related to coronavirus. Research on young children's conceptual development shows that children show interest in biological processes related to germs, viruses, illness, and healing from early ages on and inquire about them in everyday conversations (e.g., Callanan \& Jipson, 2001; Kalish, 1997). Since such biological processes are usually unobserved or unobservable and hard to explain, children's personal experiences are quite limited. Children mostly rely on the information they receive from knowledgeable adults around them (i.e., parents, teachers) when learning about such processes (Harris, 2012; Harris \& Koenig, 2006; Harris et al., 2018). The coronavirus also poses a challenging biological concept for children; it is transmitted from person to person via unobservable particles, has an incubation period, and leads to various symptoms (Haber et al., 2021). Thus, children need to solicit information from knowledgeable adults to understand the coronavirus's causes and consequences and learn how to protect themselves against the coronavirus.

Research in Western, Educated, Industrialized, Rich and Developed (WEIRD) societies highlights the role of children's questions and parents' explanations during everyday conversations for creating informal learning environments for children (e.g., Chouinard, 2007; Frazier, Gelman, \& Wellman, 2009; for a review see Ronfard et al., 2018). However, from a sociocultural perspective, children's interactions with others are shaped via socialization 
processes in the broader culture and can show differences across cultures (Greenfield et al., 2003; Rogoff, 2003; Vygotsky, 1987). Thus, when and how children ask questions and what type of information they receive in response to their questions depend on the practices and knowledge valued in a specific sociocultural context (Callanan, Solis, Castañeda, Jipson, 2020). Considering the COVID-19 pandemic's global impact, examining parent-child conversations in different sociocultural contexts can provide insight into the universal and culture-specific aspects of how children seek information about this issue and how parents inform their children about the ongoing pandemic. Thus, research examining parent-child conversations about the coronavirus in different sociocultural contexts is needed. The current study addresses this need by investigating children's questions and parents' responses about the COVID-19 pandemic in the Turkish cultural context.

\section{Children's Knowledge about Health and Illness}

Starting from an early age, children can have fragmentary observations about biological processes and develop ideas about concepts such as health and illness (Kalish, 1997). Research shows that preschoolers also start developing a relatively simple explanatory framework of how someone could get sick by catching a virus through physical proximity or contact with a sick person or touching contaminated surfaces (Kalish, 1997; Legare, Wellman \& Gelman, 2009). Specifically, preschoolers may not fully grasp the biological process of catching a virus. However, they understand that it occurs through invisible or unobservable processes (Kalish, 1997). Children's understanding of the causes and consequences of the disease also contributes to children's avoidance of sick individuals. For instance, Blacker and LoBue (2016) examined 4to 7-year-old children's understanding of the consequences of contagion and its relation to children's behavior when they interact with sick individuals. They asked children to play with 
two confederates: healthy vs. sick. They told the children that the confederate was sick and showing cold symptoms such as cough and fever. They found that only older children, 6- and 7year-olds, could make accurate guesses about the consequences of contagion and avoided contact with sick individuals and toys belonging to them (Blacker \& LoBue, 2016).

Moreover, children gradually learn about socioculturally valued knowledge and beliefs about the causes of illness and health. Thus, their reasoning about such biological processes shows differences due to their personal and sociocultural experiences (e.g., Gelman \& Raman, 2004; Hernandez et al., 2020). For instance, a recent study by Hernandez et al. (2020) examined how parents discuss the causes of the common cold with their children in two cultures: Mexican and European-American. Parents can either explain the common cold by referring to a virus or the cold weather theory, an intuitive belief that people catch a cold by staying outside in the cold. The results showed that parents from both cultures considered both virus and cold weather explanations concurrently as probable causes of the common cold. However, Mexican parents were more likely to refer to the common cold theory as a potential cause of common cold when talking with 4- and 6-year-old children. In contrast, European-American parents were more likely to refer to the virus as a probable cause of the common cold.

In sum, these findings highlight the importance of the information children receive from their parents and society when learning about culturally acceptable beliefs and knowledge about health and illness in the early years (Callanan et al., 2020). Examining children's questions about the COVID-19 pandemic can reveal children's current understanding of the coronavirus, including their knowledge gaps. Besides, parents' responses can demonstrate how parents explain germs, viruses, immunity, and vaccination to children in different sociocultural contexts. 


\section{Children's Questions and Parent's Responses}

Children's questions appear very early in their conversations; they start asking wh- and yes/no questions as soon as they start speaking, and the frequency of explanatory "why" and "how" questions increase in their conversations around 3 to 4 years of age (Chouinard, 2007; Hood \& Bloom, 1992; Hickling \& Wellman, 2001). The observational studies and diary records of parent-child conversations highlight the importance of children's questions as informationseeking tools (Callanan \& Oakes, 1992; Chouinard, 2007). Children actively seek information via asking questions about various topics (Callanan \& Oakes, 1992; Chouinard, 2007; Frazier et al., 2009; for a review see: Ronfard et al., 2018). For instance, diary studies by Callanan and her colleagues show that 4- and 5-year-olds ask about birth and human biology, physical principles of how things work (Callanan \& Oakes, 1992), natural phenomena (Callanan et al., 2019), and technological artifacts (Jipson et al., 2018).

As a response, parents tend to pay attention to children's questions and try to answer adequately (e.g., Callanan \& Oakes, 1992; Chouinard, 2007). Callanan and Oakes (1992) found that parents provided explanatory answers to 4- and 5-year-olds" "why" and "how" questions within conversational turns at least half of the time. Parents' responses were also dependent upon the type of children's questions. Specifically, in response to children's "how" questions, parents provided mechanism explanations describing the underlying processes of the event or activity. On the other hand, in response to children's "why" questions, parents mostly referred to prior causes. Children are also sensitive to the quality of answers they receive for their questions. For instance, they are persistent in repeating the same questions when they do not receive explanatory answers or provide their own explanations. However, when they receive explanatory answers, they agree or ask a follow-up question to build upon their understanding (Frazier et al., 
2009; Kurkul \& Corriveau, 2018; Ünlütabak et al., 2019). In sum, children's questions and adults' responses have great potential to contribute to children's conceptual learning in early childhood.

In an initial study, Menendez et al. (2021) examined 3- to 12-year-old children's questions and parent responses about the COVID-19 pandemic by conducting an online survey with parents in the United States (US). The findings showed that children asked questions primarily about the nature of the virus and its causes, lifestyle changes they experienced in their everyday lives, and how to protect themselves against the coronavirus. Older children were more likely to ask questions about safety and school/work, while younger children were more likely to ask about lifestyle changes. Parents responded to these questions by providing realistic explanations and emphasizing the precautions taken against coronavirus. About $35 \%$ of children's questions were explanation-seeking "why" and "how" questions. When children asked "why" and "how" questions, parents were more likely to respond with explanations. In addition, if parents reported that they had enough knowledge about coronavirus to answer their children's questions, they provided more explanations.

Another recent study by Haber et al. (2021) examined how parents in the US explained the coronavirus to their 3- to 8-year-old children via an online survey. Parents also reported children's questions about the coronavirus. The findings indicated that parents' explanations about the coronavirus made mention of germs, included comparisons to other diseases such as flu and cold, and provided information about prevention actions. Children asked about the consequences of catching the coronavirus. Older children were more likely to ask about the nature of the virus, illness, and death, while younger children asked about changes in their daily activities. Overall, these studies in the US provide insight into children's questions and parents' 
responses about the COVID-19 pandemic; however, their findings are limited to middle-SES, Western cultural contexts. Research in non-Western sociocultural contexts is needed.

\section{The Sociocultural Context}

A few studies in different sociocultural contexts indicate that when and how children ask questions and how parents respond to children's questions can differ depending on the culture in which children are raised. For instance, a cross-cultural study investigated 3- to 5-year-old children's question-asking behavior during everyday conversations in four traditional agrarian cultures (Garifuna in Belize, Logoli in Kenya, Newars in Nepal, and Samoans in American Samoa). The findings showed that children in these cultures asked significantly fewer explanation-seeking "why" and "how" questions than children in Western cultures.

Moreover, research comparing different socioeconomic statuses (SES) within the same cultural context shows that children growing up in middle-SES homes ask more explanationseeking questions than children growing up in low-SES homes (Kurkul \& Corriveau, 2018; Tizard \& Hughes, 1984). A recent study in the Turkish cultural context shows that children growing up in Turkish culture asked fewer explanation-seeking questions (22\% middle-SES and $10 \%$ low-SES) than children growing up in Western cultures, and children from middle-SES backgrounds asked more explanation-seeking questions than children from low-SES backgrounds (Ünlütabak et al., 2019). Examination of parents' responses also indicates that children from middle-SES backgrounds are more likely to receive more explanatory answers to their questions than children from low-SES backgrounds (Kurkul \& Corriveau, 2018). Different communication styles can explain these differences in different sociocultural contexts. For instance, Western cultures value independence and children's participation in conversations. In contrast, non-Western cultures emphasize being quiet and humble in conversations and may see 
question-asking as a challenge to authority. As a result, children may refrain from asking explanation-seeking questions to adults in such sociocultural contexts (Rogoff, 2003).

Building on these findings, we expect that children's questions and parents' responses about the coronavirus can also show differences due to children's sociocultural experiences. Although the impact of the COVID-19 pandemic was global, every country has had different rules and regulations in response to the pandemic. Moreover, different cultures can have different explanatory styles and coping strategies when talking about health and illness, including the coronavirus. Thus, examining children's questions and parents' responses about the coronavirus can help us reveal universal and socioculturally different aspects of parent-child conversations during the COVID-19 pandemic.

Turkish cultural context provides an excellent comparison to Western cultures and an interesting cultural context to test different sociocultural influences on children's question-asking behavior. Turkey is an industrialized and partly modernized culture. Located between the East and West, Turkey has a relational culture, which has qualities of both collectivistic and individualistic cultures (Kağıtçıbaşı, 1990, 2005). Parents in the Turkish cultural context emphasize conformity to society's expectations, obedience, respect for elders, strong emotional bonds, and there is an apparent parental authority on children. But at the same time, with urbanization, industrialization, and parents' increasing education levels, child characteristics such as developing initiative, self-regulation, and independence become part of parent socialization goals (Ataca, 2009; Sunar, 2009).

Moreover, the COVID-19 pandemic has significantly impacted Turkish people and their lifestyles. According to the World Health Organization (WHO, 2021), there have been over 9 million confirmed coronavirus cases and 81.917confirmed deaths in Turkey since March 11th, 
2020. The Turkish Ministry of Health formed a Scientific Advisory Board for the COVID-19 pandemic and took several precautions to control the spread of the COVID-19 pandemic in the country. These precautions included several complete lockdowns and other curfew measures for people over 65 who are particularly susceptible to the disease and under 18 who can carry the virus without symptoms. Except for public schools in rural areas, the schools in urban areas switched to remote education in 2020. The vaccination process in Turkey started in January 2021 and happened gradually, starting with elders and then middle adults and young adults. As of January 2nd, 2022, approximately $83 \%$ of the Turkish population above 18 received their second vaccination dose (Turkish Ministry of Health, 2022). In addition to the Ministry of Health, the Turkish Ministry of Education has disseminated resources for parents and children, informing them about the virus, precautions, and remote education during the pandemic (Turkish Ministry of Education, 2022).

\section{The Current Study}

In this study, we aim to replicate and extend Menendez et al.'s (2021) study by examining children's questions and parents' responses about the COVID-19 pandemic in Turkey to see whether parent-child conversations about COVID-19 differ in this sociocultural context. Replicating the Menendez et al. (2021) study enables us to compare our findings with the findings in the US. We also extend the previous research by examining parent-child conversations about vaccination. To the best of our knowledge, this is the first study focusing on children's questions and parents' responses about the COVID-19 pandemic in a sociocultural context outside the US. This exploratory study investigates the parental reports of children's question types and content and parents' responses to these questions. We also investigate demographic factors, parental reports of coping strategies, and anxiety levels in relation to 
children's questions and parents' answers. This study will improve understanding of universal and sociocultural different aspects of parent-child conversations about the coronavirus. This way, we can develop socioculturally sensitive guidelines for parents to talk with their children about the pandemic.

The specific research questions are as follows:

1) What are the content and type of children's questions about the coronavirus in the Turkish cultural context? Do children's questions vary by demographic factors (e.g., child age, family SES, child coping, biology knowledge, and stress)? Considering earlier findings on children's questions in the Turkish cultural context (Ünlütabak et al., 2019), we expected that children growing up in the Turkish cultural context would ask fewer explanation-seeking questions about the COVID-19 pandemic than children growing up in the US. Based on the findings from Menendez et al.'s (2021) study, we expected that children would ask questions about the nature of the virus, lifestyle changes, and precautions against the virus. Older children would ask more questions about the nature of the virus, whereas younger children would ask more questions about lifestyle changes.

2) What type of information do parents provide in response to children's questions about the coronavirus? Do parents' responses vary by demographic factors (e.g., child age, family SES, parent biology knowledge, parent enough knowledge to answer questions)? Based on Menendez et al.'s (2021) findings, we expected parents to respond to children's questions by providing information about the virus and precautions. Parents would be more likely to provide explanatory answers to children's explanation-seeking questions. Also, parents who feel more knowledgeable about the coronavirus would provide more explanatory answers than parents who feel less knowledgeable. 


\section{Method}

\section{Participants}

A total of 200 parents living in Turkey with at least one child between the ages of 3-12 participated in this study. We recruited participants for this study via schools, teachers, word of mouth, and social media. We first contacted school directors and teachers in big cities in Turkey (Istanbul, Ankara, Kayseri) and asked them to share our study with parents. Then we asked parents to share the survey with other parents that they know. We also announced the study via our social media accounts, including parent-to-parent forums and online research participation websites for young children in Turkey. The data collection process started on December $23^{\text {rd }}$, 2020, and ended by February 12 $2^{\text {th }}, 2021$ (almost a year into the outbreak of the Covid-19 pandemic). As compensation for participation in the study, an age-appropriate children's book was sent to parents' houses. However, there were entry errors and technical failures in 16 surveys yielding a final sample of 184 parents. Participants were from diverse socioeconomic backgrounds. To gather more accurate responses about the SES, we asked parents to report monthly expenses rather than asking about their income or perceived SES. This approach has proved appropriate in previous research in the Turkish cultural context (e.g., Baydar et al., 2014; Ünlütabak et al., 2019). According to parental reports, 7\% of the participants had expenses below 2500 Turkish Liras (TL), 15\% had expenses between 2500 to 3500 TL, 30\% had expenses between 3500 to 5000 TL, $21 \%$ had expenses between 5000 to 7000 TL, and $4 \%$ had expenses above $7000 \mathrm{TL}^{1}$. To facilitate comparison with Menendez et al.'s (2021) study, we presented the demographic characteristics of the Turkish and US samples in Table 1.

\section{Table 1}

\footnotetext{
${ }^{1}$ The minimum wage in Turkey was 2825 TL (approx. 380 dollars) in January 2021.
} 
Participants' Demographic Characteristics

\begin{tabular}{|c|c|c|c|c|}
\hline & \multicolumn{2}{|c|}{ Turkish Sample $(\mathrm{N}=184)$} & \multicolumn{2}{|c|}{ US Sample $(\mathrm{N}=349)^{2}$} \\
\hline & Frequency (\%) & Range & Frequency $(\%)$ & Range \\
\hline Parent age, mean (SD) & $37(5.3)$ & $26-52$ & $38.9(7.5)$ & $23-69$ \\
\hline \multicolumn{5}{|l|}{ Parent education level } \\
\hline Primary school & $8(4 \%)$ & & NA & \\
\hline Secondary school & $10(6 \%)$ & & NA & \\
\hline Some high school & $2(1 \%)$ & & $3(1 \%)$ & \\
\hline High school degree & $42(23 \%)$ & & $30(9 \%)$ & \\
\hline Some college & $1(1 \%)$ & & $58(17 \%)$ & \\
\hline Associate degree & $7(4 \%)$ & & $52(15 \%)$ & \\
\hline Bachelor's degree & $78(42 \%)$ & & $147(42 \%)$ & \\
\hline Master's degree & $21(11 \%)$ & & $48(13 \%)$ & \\
\hline Doctoral level degree & $15(8 \%)$ & & $11(3 \%)$ & \\
\hline Household size, mean (SD) & $4.02(.93)$ & $2-7$ & $4(2.8)$ & $2-10$ \\
\hline Child age, mean (SD) & $7.6(2.5)$ & $3-12$ & $7.8(3.1)$ & $3-12$ \\
\hline Child gender (\%) & Girls $=53.6 \%$ & & Girls $=46.7 \%$ & \\
\hline $\begin{array}{l}\text { Parent biology knowledge, } \\
\text { mean (SD) }\end{array}$ & $4.4(1.7)$ & $1-7$ & $4.4(1.1)$ & $1-7$ \\
\hline $\begin{array}{l}\text { Child biology knowledge, } \\
\text { mean (SD) }\end{array}$ & $2.9(1.8)$ & $1-7$ & $3.4(1.4)$ & $1-7$ \\
\hline \multicolumn{5}{|l|}{ Anxiety, ${ }^{3}$ mean $(\mathrm{SD})$} \\
\hline Parent & $7.2(2.4)$ & $0-10$ & $7.1(3)$ & $0-10$ \\
\hline Child & $6.1(2.6)$ & $0-10$ & $5.1(3.1)$ & $0-10$ \\
\hline Family & $7.2(2.2)$ & $0-10$ & $7(2.6)$ & $0-10$ \\
\hline \multicolumn{5}{|l|}{ Worry, mean (SD) } \\
\hline Parent & $7.2(2.3)$ & $0-10$ & $7.4(2.8)$ & $0-10$ \\
\hline Child & $6.2(2.6)$ & $0-10$ & $5.4(2.9)$ & $0-10$ \\
\hline Family & $7.3(2.2)$ & $0-10$ & $7.4(2.4)$ & $0-10$ \\
\hline \multicolumn{5}{|l|}{ Coping, mean (SD) } \\
\hline Parent & $7(2)$ & $0-10$ & $8(2.4)$ & $0-10$ \\
\hline Child & $6.8(2.2)$ & $0-10$ & $7.9(2.7)$ & $0-10$ \\
\hline Family & $7(1.9)$ & $0-10$ & $8.2(2.2)$ & $0-10$ \\
\hline
\end{tabular}

\section{Materials and Procedure}

${ }^{2}$ Comparative data from a US sample reported in Menendez et al., 2021

${ }^{3}$ We conducted a linear mixed-effects model to examine whether there were differences in parental reports of worry, anxiety and coping. There was a significant effect of question type (parent, child, family), $F_{\text {worry }}(2,179)=$ $21.82, F_{\text {anxiety }}(2,179)=26.26, \mathrm{p}<.001, \mathrm{p}<.001, F_{\text {coping }}(2,179)=3.48, \mathrm{p}<.05$. Parents reported significantly higher worry, anxiety and coping strategies for themselves $t_{\text {worry }}(180)=5.98, \mathrm{p}<.001, t_{\text {anxiety }}(179.99)=6.42, \mathrm{p}<$ .001 , $t_{\text {coping }}(180)=2.01, \mathrm{p}<.05$ and for their families $t_{\text {worry }}(180)=6.57, \mathrm{p}<.001$, $t_{\text {anxiety }}(179.99)=7.26, \mathrm{p}<.001$, $t_{\text {coping }}(180)=2.61, \mathrm{p}=.009$ than for their children. 
We adopted the survey from Menendez et al. (2021). Our version of the survey consisted of 7 sections (67 questions in total) and was administered online via Google Forms software. The sections were as follows: 1) Demographic Characteristics, 2) Anxiety and Coping, 3) Child Questions and Parent Responses, 4) Biology and Virus Knowledge, 5) Shielding and News, 6) Vaccination, 7) Coping Strategies. If parents had more than one child within the age group of this study, we asked them to focus on one child and answer the questions in each section accordingly. We provide the details about each section below.

\section{Demographic Characteristics}

Parents were presented with demographic questions after completing the informed consent form. There were 27 demographic questions asking parents to report their children's age, gender, household size, parent education levels, occupation, and monthly family expenses.

\section{Anxiety and Coping}

Parents answered 9 questions about anxiety and coping levels of themselves (parent), their child, and their family. Specifically, we asked parents to report how worried, and anxious they/their child/their family felt about the COVID-19 pandemic. We also asked parents how they/their child/their family were coping with the COVID-19 pandemic. Parents completed ratings on a 0 -10 Likert scale $(0=$ not at all; $10=$ extremely $)$. The internal reliability for stress was $\alpha=$ .84 ; for anxiety was $\alpha=.86$, and for coping was $\alpha=.90$. We conducted an exploratory factor analysis (EFA) for this measure. Questions about stress and anxiety loaded on the same factor, and all items could load on one factor as in the original study (Menendez et al., 2021). The factor including stress and anxiety measures explained $45 \%$ of the variance while the coping factor explained $25 \%$ of it. 


\section{Child Questions and Parent Responses}

To examine children's questions and parents' responses, we first presented parents with 3 open-ended questions to report their children's questions about the COVID-19. Then we asked parents to report how they responded to these questions. In addition to these open-ended reports of questions, we provided parents with a list of 10 already formulated questions (e.g., "Why do we use hand sanitizer?"). We asked parents whether their children asked these questions or not. If they said "yes," we asked them to report how they responded to these questions. As part of this section, we asked parents whether they observed any change in the content of their children's questions after the pandemic by selecting "yes" or "no" options. If parents said "yes," we asked them to describe their observed changes.

\section{Biology and Virus Knowledge}

We presented parents with 3 questions evaluating their and their child's knowledge about biology. The first two questions asked parents to report how knowledgeable they think they (parent) and their child are about biology on a $0-7$ Likert scale $(0=$ not at all, $7=$ very much). The third question asked parents to rate whether they feel knowledgeable enough to answer their child's coronavirus-related questions adequately on a $0-7$ Likert scale $(0=$ strongly disagree, $7=$ strongly agree). The correlations between parent biology knowledge and parental years of education were calculated to show the convergent validity of the parent biology knowledge questions. A significant positive correlation was found, $r(173)=.29, p<.001$.

\section{Shielding}

We presented parents with five options related to whether they shield their children from the news on this topic in conversations. Parents were able to select all options that applied to them. The options were: "I don't want to worry her/him," "I don't think my child can handle this 
emotionally," "I don't think they are old enough to understand this situation," "I am not trying to protect my child from news about Covid-19 from media reports" and "I think Covid-19 is no different than seasonal flu". Depending on parents' answers, we also asked them to describe how they discuss the news related to the COVID-19 pandemic with their children.

We also presented parents with 2 questions related to the news. The first one asked them to report how frequently they followed any news in the media. The second one asked them to report how frequently they discussed the news with their children on a $0-5$ Likert scale $(0=$ never, $5=$ always). Finally, we asked parents whether they encountered any advice in the media that they found helpful for answering children's questions related to the COVID-19 pandemic. If they said "yes," we asked them to explain how it influenced their responses to children's questions.

\section{Coping Strategies}

We presented parents with 2 open-ended questions to report any coping strategies they used as a family during the pandemic. The first question asked about family coping strategies in general. The second question asked whether there is any additional information they would like to share about their family coping strategies.

\section{Vaccination}

We asked parents 3 questions about the vaccination. In the first question, we asked parents to report their attitude towards vaccination by selecting among 5 statements representing different attitudes (e.g., I think the COVID-19 vaccine will be very protective, I am not interested in the COVID-19 vaccine). In the second question, we asked parents whether they discussed vaccination with their children or not. If parents answered "yes," we asked them an open-ended question to describe how they discuss vaccination with their children. 


\section{Coding and Data Preparation}

We coded the content and type of children's questions and parents' responses as reported in the open-ended questions of the survey. We adopted the coding categories from the Menendez et al. (2021) study and used a total of 6 coding schemes. Appendix in the Supplementary Materials includes all coding schemes with definitions and examples. The coding schemes were as follows: 1) The content and type of children's questions (Table 1 in Appendix), 2) The content and type of parents' responses (Table 2 in Appendix), 3) Children's explanation-seeking questions and the match between children's questions and parents' responses (Table 3 in Appendix), 4) parents' responses to children's explanation-seeking questions (Table 4 in Appendix), 5) parental descriptions about the changes in children's questions during the pandemic (Table 5 in Appendix), and 6) parental reports about coping strategies (Table 6 in Appendix). Three research assistants coded the data. Before coding, the research assistants reviewed the coding schemes and examples with the first author. The first author independently coded $20 \%$ of the data coded by the research assistants. Cohen's Kappa ( $\kappa)$ was calculated as a measure of agreement between the first author and three coders for all codes of children's questions and parents' responses. The agreement for children's questions was 0.92 and for parents' responses was 0.88 . All disagreements were resolved via discussion.

\section{Children's questions}

We coded children's questions for five content categories: 1) virus, 2) safety, 3) preventive measures, 4) school/work, and 5) interpersonal relations (see Table 1 in Appendix for definitions and examples). 


\section{Parents' responses}

We coded parents' responses for five mutually exclusive: 1) authority, 2) realistic, 3) supernatural, 4) no explanation, 5) other, and two non-mutually exclusive categories: 1) reassurance, 2) religious concepts. Third, we identified children's explanation-seeking "why" and "how" questions and whether parents' responses for these questions match the question type. For his purpose, first, we checked if the parent provided short, one-word answers for children's questions. Then we looked at the match between the children's questions and parents' responses by considering three categories: 1) evades, 2) evades and elaborates by changing the topic, 3) answers questions (see Tables 2- 4 in Appendix for definitions and examples).

\section{Changes in children's questions}

We dummy coded the parents "yes" = 1 and "no" = 0 responses for changes in children's questions. If parents reported a change in children's questions, we coded their responses according to 5 categories: 1) health, 2) personal/family/friends' safety, 3) lifestyle changes and preventative measures, 4) changes in the number of questions, 5) other (see Table 5 in Appendix for definitions and examples).

\section{Coping strategies}

We coded coping strategies for 1) no strategy, 2) acting like nothing happened, 3 ) treat like a vacation, 4) prayer/mosque, 5) keep a schedule/regular routine, 5) Covid-19-related, 6) family activities, 7) social interaction, 8) education, 9) other (see Table 6 in Appendix for definitions and examples). The responses of the participants who misunderstood the question answered in a way that could not be evaluated, gave an answer in the question part, or wrote a question in the answer part were considered as entry errors and coded as "99". Before the statistical analysis, 99 coded data were defined as NA (not available) and were not included in the analyses. Since the 
questionnaire form allowed parents to pass without answering a question if they wanted, the number of available data in the analyzes differed slightly.

\section{Vaccination}

The content categories for coding parents' responses about the COVID-19 pandemic used by Menendez et al., 2021 were also appropriate for coding the open-ended answers reflecting parents' attitudes about vaccination. Thus, we used the same coding scheme, but we added a timing category as parents discussed the vaccine schedule and when they would be vaccinated. Overall, we had 6 mutually exclusive coding categories: 1) authority, 2) realistic, 3) supernatural, 4) no explanation, 5) timing, and 6) other, and three non-mutually exclusive categories: 1) repetitive, 2) reassurance, 3) religious concepts.

\section{Results}

To address our research questions and compare the findings in the Turkish sample with the findings in the US sample, we conducted the same descriptive and inferential analyses as Menendez et al. (2021) study in R statistical software. We also included the frequency and percentages of the US data along with the Turkish data in our tables. First, we examined the content and type of children's questions about the coronavirus and whether they vary by demographic factors (e.g., child age, family SES, child coping, biology knowledge, and stress). Second, we examined parents' responses to children's questions and whether they vary by demographic factors (e.g., child age, family SES, parent biology knowledge, parent enough knowledge). We conducted generalized linear mixed model analyses. We used the lme4 package (Bates et al., 2015), the car package (Fox \& Weisberg, 2019), the lmSupport package (Curtin, 2018) for the linear models in our study. For the models we build for children's questions, we 
entered child age, family SES, child biology knowledge, child coping, and child stress ${ }^{4}$ as predictors. When running models for parents' responses, we also entered parent biology knowledge and parent enough knowledge as predictors.

\section{The Content and Type of Children's Questions}

We asked parents to report the percentage of times their children initiated COVID-19 pandemic-related conversations in general and found that children initiated $41.48 \%$ of the conversations $(S D=29.89 \%$, Range $=0-100 \%)$. Parents reported a total of 472 questions asked by their children about COVID-19, with an average of 2.60 questions per child. We found that children asked virus-related questions frequently, such as "What does coronavirus mean?", "Why is the virus so small?" $(n=161,34.1 \%)$. Besides, children asked questions about the changes the pandemic had brought to our lives $(n=93,19.7 \%)$, their schools, and their parents' jobs $(n=62,13.1 \%)$, the measures we needed to take due to the pandemic $(n=57,12 \%)$, their safety or the safety of their loved ones $(n=56,11.9 \%)$. The least frequently asked question content was about interpersonal relations and included questions like "When will I meet my friends?", "When will my friends come to our house?" $(n=21,4.4 \%)$. The questions that did not fall into any of the listed categories were classified as other and constituted $4.6 \%$ of the questions $(n=22)$. Overall, the content of children's questions was slightly different in the Turkish sample than in the US sample. Table 2 shows the frequencies of children's questions by content.

The findings from the linear mixed models for children's questions replicated Menendez et al.'s findings with the US sample. Older children tended to ask fewer questions about lifestyle changes $(O R=.82, \chi 2(1, N=166)=12.43, p<.001)$ than younger children. Also older children tended to ask more questions about school/work $(O R=1.15, \chi 2(1, N=166)=5.54, p=.02)$ than

\footnotetext{
${ }^{4}$ To allow for comparisons, we calculated child and parent stress variables by averaging parental reports of worry and anxiety as it was calculated in Menendez et al., (2021).
} 
younger children. We also found that children who were coping well with the new conditions that have arisen as a result of the Covid-19 pandemic, according to parental reports, were more likely to ask questions about safety $(O R=1.24, \chi 2(1, N=166)=4.64, p=.03)$ and less likely to ask questions about lifestyle changes $(O R=.88, \chi 2(1, N=166)=4.48, p=.03)$. Finally, children whose parents thought they were stressed about Covid-19 outbreak were found to ask more questions about safety $\left(O R=1.12, \chi^{2}(1, N=166)=6.39, p=.01\right)$. The biology knowledge and the SES were not associated with any type of question.

\section{Table 2}

Frequency of Questions Asked (Percentages) by Question Content

\begin{tabular}{lcccc}
\hline & \multicolumn{2}{c}{ Turkish Sample $(\mathrm{N}=184)$} & \multicolumn{2}{c}{ US Sample $(\mathrm{N}=349)$} \\
\hline Question Content & $\begin{array}{c}\text { All } \\
\text { Questions }\end{array}$ & $\begin{array}{c}\text { Explanation } \\
\text { Questions }\end{array}$ & $\begin{array}{c}\text { All } \\
\text { Questions }\end{array}$ & $\begin{array}{c}\text { Explanation } \\
\text { Questions }\end{array}$ \\
\hline Virus & $161(34 \%)$ & $34(40 \%)$ & $168(17 \%)$ & $77(22 \%)$ \\
Safety & $56(12 \%)$ & $9(10 \%)$ & $178(18 \%)$ & $19(5.5 \%)$ \\
Precautions & $57(12 \%)$ & $16(19 \%)$ & $32(3.3 \%)$ & $27(7.9 \%)$ \\
Lifestyle Changes & $93(20 \%)$ & $20(23 \%)$ & $233(24 \%)$ & $102(30 \%)$ \\
School/ Work & $62(13 \%)$ & $1(1.2 \%)$ & $185(19 \%)$ & $46(13 \%)$ \\
Social Relations & $21(4.4 \%)$ & $4(5 \%)$ & $134(14 \%)$ & $58(17 \%)$ \\
Other & $22(4.6 \%)$ & $1(1.2 \%)$ & $42(4.3 \%)$ & $13(3.8 \%)$ \\
Total & 472 & 85 & 972 & 342 \\
\hline
\end{tabular}

In the next step, the questions asked by the children were coded according to whether they were explanation-seeking or not, and only $18.2 \%$ of the questions were explanation-seeking $(\mathrm{n}=85)$ as opposed to $35 \%$ in the US sample (Menendez et al., 2021). When we compared the content of children's explanation-seeking questions, we found that the highest number of explanation-seeking questions were related to the virus $(n=34,40 \%)$, followed by lifestyle changes $(n=20,23.5 \%)$, prevention-related issues $(n=16,18.8 \%)$, personal safety $(n=9$, $10.5 \%)$, and interpersonal relationships $(n=4,4.7 \%)$. Only $1.2 \%$ of questions about work or school were explanation-seeking $(n=1)$. Children who were less stressed by the pandemic, 
according to parental reports, were found to be more likely to ask explanation-seeking questions $(O R=.87, \chi 2(1, N=166)=6.71, p=.01)$.

We asked the parents if they had observed any changes in their child's health or illnessthemed questions over the past months, and most of the parents reported that they observed changes $(n=101,57.3 \%)$. If parents reported that they observed changes, we asked them to describe the differences they observed. Parents stated that children mostly started asking questions about health and included themes such as biology, life, and death $(n=25,25.2 \%)$. For example, one parent reported that "As they heard about the new research results on the virus, they started asking questions about them, such as what is a mutation, etc." Some parents stated that the changes in the questions were based on lifestyle changes and preventive measures $(n=$ $14,14.1 \%)$, personal or loved one's safety $(n=8,9 \%)$. There were also answers classified as other because they did not fall into any category $(n=32,32.3 \%)$. These answers were mostly about how their children were worried about the pandemic and how parents provided reassurance. Some parents stated an increase in the number of questions $(n=10,10.1 \%)$, while the rest stated a decrease $(n=9,9 \%)$.

\section{The Content and Type of Parents' Responses}

Following children's questions, we examined the content of the answers given by the parents to these questions. A total of 447 responses were reported. As we coded parents' responses using both mutually exclusive and non-mutually exclusive codes, there were a total of 538 codes assigned to all responses (see Table 3 ). Parents mostly provided realistic explanations to their children's questions $(n=257,47.8 \%)$. For example, to a child who asked a question like “When will we stop wearing masks?" a parent gave a realistic answer by saying, "We will not need to wear a mask when the coronavirus is completely over." Apart from that, the parents 
included themes such as reassurance $(n=106,19.7 \%)$, authority $(n=49,9.1 \%)$, and religion $(n$ $=26,4.8 \%$ ) in their answers. Parents did not give any explanation to their children's questions in $14.4 \%$ of their answers $(n=78)$, and $4 \%$ of the answers were classified as other because they did not fall into other classes $(n=22)$. None of the parents' answers included supernatural items in their answers.

Most parents responded to their children's questions appropriately $(n=392,89.9 \%)$ rather than just evading their children's questions or providing answers about irrelevant issues. Only a small portion of the parents responded to their children's questions by evading $(n=13$, $2.9 \%$ ) or explaining a topic unrelated to their children's questions $(n=31,7.1 \%)$. For example, to a child who asked a question like "When will the Covid-19 outbreak end?" the parents answered by saying, "Coronavirus is a disease, healthy ones will not be affected."

We also examined parents' responses to children's explanation-seeking questions. Parents were more likely to provide explanatory answers for these questions $(O R=2.70, \chi 2(1, N$ $=159)=9.02, p=.003)$ than non-explanation seeking questions. Also, consistent with the findings in the US data (Menendez et al., 2021), we found that parents' biology knowledge and judgments about their knowledgeability about COVID-19 were associated with parents' explanatory answers. Parents who reported themselves knowledgeable enough to answer their children's questions about Covid-19 were more likely to provide explanations $(O R=1.25, \chi 2(1$, $N=160)=6.27, p=.01)$.

\section{Table 3}

Frequency of Parents' Responses (Percentages) by Content

\begin{tabular}{|c|c|c|}
\hline Content & Frequen & $(\%)$ \\
\hline 1. Mutually exclusive & Turkish Sample & US Sample \\
\hline
\end{tabular}




\begin{tabular}{lll} 
Authority & $49(10.9 \%)$ & $58(6 \%)$ \\
No Explanation & $78(17.3 \%)$ & $509(52.7 \%)$ \\
Realistic Explanation & $257(57.1 \%)$ & $347(36 \%)$ \\
Supernatural & 0 & $13(1.3 \%)$ \\
Other & $22(4.9 \%)$ & $38(3.9 \%)$ \\
\hline
\end{tabular}

2. Non-mutually exclusive

\begin{tabular}{lll}
\hline Reassurance & $106(23.5 \%)$ & $128(13.3 \%)$ \\
Religious concepts & $26(5.8 \%)$ & $7(0.7 \%)$ \\
\hline
\end{tabular}

After examining open-ended parental reports of children's questions, we examined parental checks from our list of 10 already formulated questions (e.g., "Why do we need to wash our hands?"). Parents reported whether their children asked these questions or not and if they answered "yes," they reported how they answered these questions. The list of the questions was the same for all the parents. In Table 4, we provide the frequencies and percentages of parents who answered "yes" in response to whether their children asked the given question or not in the Turkish sample and the US sample.

\section{Table 4}

The Frequencies and percentages of parental reports of children's particular questions

\section{Frequency}

\begin{tabular}{lcc}
\hline Questions & Turkish Sample & US Sample \\
\hline Why do we need to wash our hands? & $92(50 \%)$ & $134(38.4 \%)$ \\
Why should we use hand sanitizer? & $94(51.1 \%)$ & $101(28.9 \%)$ \\
Why can we not go to school? & $121(65.7 \%)$ & $253(72.5 \%)$ \\
Why can we not go to the park? & $131(71.1 \%)$ & $239(68.5 \%)$
\end{tabular}


Why are we not allowed to go outside? $\quad 144(78.2 \%) \quad 213(61 \%)$

What does social distancing mean? $\quad 81(44 \%) \quad 265(75.9 \%)$

Parents usually answered these questions with direct or indirect reference to the Covid-19 outbreak $(n=649,49.1 \%)$. The rest of the parents answered by mentioning the safety of themselves, their children, or their families $(n=501,37.9 \%)$. For example, to a child who asked why they couldn't go out, the parent replied, "We shouldn't go out to protect both ourselves and other people unless it is necessary." Some parents emphasized their authority or official authority in their responses $(n=100,7.6 \%)$. For example, to a child who asked why they could not go to the park, the parent said, "There is a ban at these times. We must follow the rules." Only a few parents mentioned social responsibility $(n=38,2.9 \%)$. Parents rarely gave answers that contradicted the social norms during the pandemic. $(n=9,0.6 \%)$. The remaining answers that do not fit into any category were classified as other $(n=23,1.7 \%)$. In Menendez et al. (2021), there was also a category called supernatural; however, none of the parents in our sample provided an answer referring to supernatural elements.

We examined whether the content of the explanatory answers provided by parents for children's questions differs according to the topics of questions. For this purpose, we placed questions about washing hands or using disinfectants under hygiene categories and questions about not going to the park, not going to school, not going out, and social distancing under the stay home categories. Parents were more likely to provide protection-based explanations to their children's hygiene questions, $O R=4.33, \chi^{2}(1, N=156)=20.69, p<.001$ than stay home questions. Parents with higher SES were found to be less likely to provide protection-based explanations, $O R=1.44, \chi^{2}(1, \mathrm{~N}=156)=6.14, p=.01$ than parents with lower SES. The effects 
of other predictors such as parent biology, child biology, having enough knowledge, child age, parental reports of child stress, and child coping were not significant.

\section{Shielding, News, Media, and Family Discussions}

We examined whether parents protected their children from news or media related to the COVID-19 pandemic. While some parents stated that they did not protect their children from news or media sources related to the pandemic $(n=73,42.2 \%)$, the remaining parents said they $\operatorname{did}(n=100,57.8 \%)$. If parents reported that they shielded their children from COVID-19 related news, we also asked them to select several statements explaining why they shielded children from the news and select those that apply to them. Parents mainly reported not wanting to worry their children $(n=102,37.91 \%)$. Parents also said that they did not think their children were old enough to understand the pandemic $(n=61,22.77 \%)$ and emotionally mature enough to cope with it $(n=23,8.55 \%)$.

We also asked the parents how often they watch the news together as a family. The majority of the parents said that they "sometimes" watch the news together $(n=63,35.2 \%)$, followed by "often" ( $n=47,26.2 \%)$, "rarely" ( $\mathrm{n}=34,18.9 \%)$, "never" $(n=21,11.7 \%)$ and "always" ( $n=7.8 \%)$. Parents who shielded their children from news and media sources were less likely to watch the news with their children $(O R=.47, \chi 2(1, N=159)=51.98, p<.001)$ than parents who did not shield. Parents with a higher socioeconomic level were found to be more likely to shield their children from these sources than parents with a lower socioeconomic level $(O R=1.22, \chi 2(1, N=159)=4.62, p=.03)$.

Regarding the media, we asked parents how often they talked or commented on the news after watching the news as a family. Parents mostly stated that they "sometimes" talk after watching news together $(n=61,34.6 \%)$, followed by "rarely" $(n=44,25 \%)$, “often" $(n=34$, 
$19.3 \%)$, "never" ( $n=27,15.3 \%)$ and "always" ( $n=10,5.6 \%)$. In addition, we asked parents if they encountered any advice from the media or any other source explaining how parents should talk to their children about Covid-19. The majority of the parents said that they had not encountered any advice $(n=116,64.8 \%)$, while the rest answered "yes" to this question $(n=63$, $35.2 \%)$. Another question we asked about the media was whether the information they came across was reflected in their conversations with their children. While most parents reported that the recommendations were not reflected in their conversations $(n=116,68.6 \%)$, some parents said they benefited from these recommendations $(n=53,31.3 \%)$. As expected, parents who said they came across advice from the media or any other source on how to talk to their children about Covid-19 were more likely to reflect this advice in their responses $(O R=13.46, \chi 2(1, N=$ $159)=118.35, p<.001)$. In addition, parents from higher SES families were more likely to report that they saw advice about how to talk to children about the virus $(O R=1.51, \chi 2(1, N=$ $159)=14.04, p<.001)$ than parents with lower SES families. Moreover, parents who thought they had enough knowledge about coronavirus $(O R=1.29, \chi 2(1, N=159)=8.10, p=.004)$ and rated their general biology knowledge lower $(O R=.83, \chi 2(1, N=159)=4.1, p=.04)$ were found to be more likely to report that they encountered an advice from media sources.

\section{Coping Strategies}

When parents' coping strategies related to Covid-19 were examined, it was found that the most common strategy was to do different kinds of activities $(n=106,69.2 \%)$. Apart from this, strategies such as engaging in social relations $(n=48,31.3 \%)$, COVID-oriented behaviors $(n=$ $46,30 \%)$, and religious activities were used the most $(n=35,22.8 \%)$. A small portion of the parents said that they applied different strategies such as homeschooling $(n=4,2.5 \%)$, treating 
the situation as vacation $(n=2,1.3 \%)$ and keeping a regular routine $(n=1,0.6 \%)$ and some of them did not implement any strategy $(n=7,4.57 \%)$.

\section{Vaccination}

Most parents reported their concerns about the side effects of the COVID-19 vaccine ( $n=$ $108,60 \%$ ). But still, about $40 \%$ of the parents reported that they are very excited about the vaccination and believe that it will be protective $(n=76)$. When we asked parents whether they talk about vaccines with their children, only 123 parents responded to this question, and 55 $(44 \%)$ of them reported that they do not talk about vaccines with their children. We coded the open-ended responses of the remaining $58(56 \%)$ parents who talked about vaccination with their children. We found that parents provided realistic explanations $(n=27,47 \%)$ about how vaccines would protect us. Parents also provided reassurance for their children $(n=17,29 \%)$. The rest of the discussions were about the timing and logistics of the vaccination $(n=8,14 \%)$ and acknowledging the vaccination, but without an explanation $(n=10,17 \%)$ and other $(n=7$, $12 \%)$.

We conducted a logistic regression model to determine whether the parent and child biology knowledge, child age, SES, child coping and stress, and parent enough knowledge predicted whether parents talk about vaccines with their children or not. Only one predictor was significant; we found that parents who reported their children to be more stressed were more likely to talk about vaccinations with their children $(O R=1.06, \chi 2(1)=6.82, p=.009)$ than parents who reported their children to be less stressed. 


\section{Discussion}

This study examined children's questions and parents' responses about the COVID-19 pandemic in the Turkish cultural context. Our findings were in line with the findings in the US (Menendez et al., 2021); but also showed some differences. Our first research question focused on the content and type of children's questions about the coronavirus and whether children's questions vary by demographic factors. Our findings showed that children's questions were mostly about the nature of the virus (34\%), followed by lifestyle changes $(20 \%)$. When compared to the findings in the US, we observed virus questions more frequently in the Turkish sample than in the US sample, whereas there were more lifestyle change questions in the US sample than in the Turkish sample. This finding could be attributed to the sociocultural differences in the adaptation process to the changes brought about by the pandemic. Questions can reflect children's knowledge gaps or their need for information on specific topics. Such differences in questions may indicate that children in the US may have more difficulty adapting to the changes in their lives and inquire more about the lifestyle changes. In contrast, children in Turkey have more difficulty understanding the nature of the virus and inquire more about the virus. However, these differences should be interpreted carefully because they are confounded by the timing of the survey in the US vs. Turkey. Menendez et al., 2021 completed the survey in April 2020 when the pandemic had just started, and we were just adjusting our lifestyles accordingly. We conducted the survey in January 2021; almost a year elapsed since the start of the pandemic when we had mostly adjusted our lifestyles but were still trying to understand the nature of the virus with all its mutations, and variants, and efforts to develop vaccinations. As parents reported in our study, the process of change due to the pandemic and the news on the media influence the ongoing conversations at home, and thus, children's questions. 
The age-related differences in the content of children's questions were similar in the US and Turkish samples. Replicating Menendez et al.'s findings, we found that older children were more likely to ask questions about school and work than younger children. In comparison, younger children were more likely to ask about lifestyle changes than older children. These findings suggest that younger children have a more challenging time adjusting to changes in their everyday routines than younger children. On the other hand, school and work questions were more relevant for older children. According to parental reports, in the US sample, children were coping well with the pandemic, and highly stressed children were more likely to ask virus questions. Highly stressed children were also more likely to ask about safety, interpersonal relations, and lifestyle changes. In the Turkish sample, again, according to parental reports, children who were coping well and highly stressed tended to ask more safety-related questions. Children who were highly stressed and not coping well with the pandemic also showed a tendency to ask about lifestyle changes. These similarities and differences suggest that children in both sociocultural contexts were concerned about the consequences of the pandemic and inquired about how to be safe within this situation. In the US sample, but not in the Turkish sample, children focused more on virus-related questions if they were considered as highly stressed by their parents.

Corroborating the earlier findings in Turkish cultural context (Ünlütabak et al., 2019) and other non-Western cultural contexts (Gauvain et al., 2013), children in the Turkish sample asked fewer explanation-seeking questions about the coronavirus (18\% of all questions) than children in the US sample (35\% of all questions) (Menendez et al., 2021). Children in the Turkish cultural context ask yes/no and what type of questions more frequently, focusing on factual information related to the coronavirus rather than questions focusing on explanations in the company of 
adults. One possible explanation for these differences can be differences in parental mindsets and values (independence vs. obedience and respect for elders) about how to prepare children for social life and communicate with others in the broader sociocultural context (Callanan et al., 2020; Feldman, 2003; Harkness et al., 2015). Another possible explanation is parental education levels. The parental education levels were relatively higher in the US sample than in the Turkish sample. In the Turkish sample, about $34 \%$ of parents reported having a high school degree or less, whereas, in the US sample, only $10 \%$ of the parents reported having a high school degree or less. Parents who had higher education levels may encourage more school-like conversations at home than parents who had lower education levels; thus, children may become more likely to ask explanation-seeking questions (Gauvain \& Munroe, 2020; LeVine et al., 2012; Rogoff, 2003; Ünlütabak et al., 2019). Also, if parents reported their children to be less stressed, children were more likely to ask explanation-seeking questions in the Turkish sample. These findings suggest that children's "why" "how" questions about the pandemic may be more common when there is a less stressful environment and when parents consider their children to be less stressed about the pandemic. Future research should look into social and emotional factors influencing children's question-asking behavior in different sociocultural contexts.

Our second research focused on the type of information parents provide in response to children's questions about the coronavirus. Similar to the findings in the US sample (Menendez et al., 2021), parents in the Turkish sample provided answers to their children's questions rather than avoiding them or giving irrelevant answers. Although children's explanation-seeking questions were not very frequent, parents responded to children's questions primarily by providing realistic explanations (48\%) and reassurance (20\%). Also, parents were more likely to provide explanations when they reported that they had enough knowledge about the coronavirus. 
Supporting the findings from earlier research, parents provided contingent responses to children's questions (Callanan \& Oakes, 1992; Chouinard et al., 2007). Parents were more likely to provide explanations if children's questions were explanation-seeking. Parents also adjusted the content of their explanations based on children's questions. Replicating the findings in the US sample, we found that if children asked hygiene questions, parents provided protection-based answers. There were no SES-related differences in the US sample about parents' protectionbased explanations. In the Turkish sample, we found that parents from lower SES backgrounds tended to provide more protection-based explanations to their children for hygiene questions than parents from higher SES backgrounds. This finding can be explained in relation to the differences in the family home environments. Research shows that families from high SES backgrounds have better access to resources such as healthcare, nutrition, optimal sanitary conditions than families from low SES backgrounds (Evans, 2004). Besides, when resources are limited, parents' child-rearing practices are also shared accordingly and focus on protecting and ensuring the child's safety (LeVine et al., 1994). Thus, in a situation like a pandemic, parents from low SES backgrounds in the Turkish sociocultural context may need to place extra emphasis on the protection-based explanations to ensure hygiene and protect themselves and their children against the virus. Our findings also showed that a higher percentage of parents in the Turkish sample reported that their children asked more questions about handwashing and using hand sanitizers than children in the US sample (see Table 4). Additional research is required to explore how parents and children discuss health and hygiene practices in different SES groups and sociocultural contexts.

The majority of the parents in our study reported that they shielded their children from media news about the COVID-19 pandemic, which supported the earlier findings in the US, 
showing that parents do not prefer to talk about stressful topics like illness and death with young children (Menendez et al., 2021; Rosengren et al., 2014). When asked to explain why they shield their children from the news, parents said that they did not want to worry their children, and they referred to children's maturity and said that their children were not old enough to understand the situation. These findings corroborated Menendez et al. (2021) and indicated that parents in Turkey also try to protect their children from news in the media by referring to similar reasons as the US parents.

In Menendez et al. (2021), parents reported participating in family activities, keeping a routine, and social interaction as helpful coping strategies. Parents in the Turkish sample also reported similar coping strategies such as family activities and social interaction. In addition, they reported that praying during these times is also a helpful strategy for them. However, they did not mention keeping a routine. This finding can also be due to differences in parental education levels in the US and Turkish samples. Parental education levels together with sociocultural context can influence the parent-child daily activities and socialization practices. Parents with high education levels may prefer school-like routines and regular schedules in their everyday lives. While parents with low education levels spend time idly with their children just relaxing or socializing (Lareau, 2000; Levine et al., 2012; Rogoff, 2003). In future work, it will be very interesting to examine parent-child coping strategies across different sociocultural contexts and the socialization goals underlying these differences.

Our findings also provided insight into how parents may be talking about vaccination with their children. Only a small portion of the parents in our sample mentioned vaccination, and they needed to have the vaccination for protection. Still, they do not necessarily explain how vaccines work for their children. It is possible that at the time of our data collection, parents 
themselves were not completely confident about the biological processes involved in vaccination processes because many parents reported that they were concerned about the side effects of the vaccination. Another possibility is that parents think this topic is too complex for children and, as a result, just focus on protection and reassurance. However, we also found that parents who reported that their children have high stress levels were more likely to talk about vaccination. It is possible that parents engaged in talk about vaccination to manage their children's stress about vaccination and assure them the pandemic would be over.

\section{Limitations}

Although the findings from this study provide insight into understanding parent-child conversations about the COVID-19 pandemic in a different sociocultural context, some limitations need to be acknowledged. To the best of our knowledge, this study was the first study conducted in a sociocultural context different from the WEIRD cultures, and findings provide a direct comparison to findings in the US (Menendez et al., 2021). However, this study is limited to the Turkish cultural context and only provides an initial step towards understanding sociocultural differences in parent-child conversations about the coronavirus. More research in different SES groups and sociocultural contexts is needed. Second, we rely on parental reports of children's questions and parents' responses. Similar diary methods have been used effectively to examine children's questions before (Callanan \& Oakes, 1992; Chouinard et al., 2007). Findings support and extend the earlier experimental work on children's questions in the Turkish cultural context (Ünlütabak et al., 2019). However, naturalistic observations are needed to have a more comprehensive picture of children's questions and parents' responses about the coronavirus.

Future research should use various methods (e.g., observations, experiments) to examine parentchild conversations about the COVID-19 pandemic. 


\section{Conclusions}

This study contributes to the research on parent-child conversations about the COVID-19 pandemic in different sociocultural contexts. The findings from this study highlight the universal and culture-specific aspects of children's questions about the coronavirus and how parents respond to these questions in everyday conversations. According to parental reports, similar to children growing in the US, children in the Turkish cultural context inquired about different aspects of the COVID-19 pandemic in parent-child conversations. Parents responded to children's questions in an informative way. However, the type and content of children's questions (more virus-related questions and fewer explanation-seeking questions in the Turkish cultural context) and the information parents emphasized in their responses showed differences depending on SES and demographic factors, and culture. In future work, it is important to explore further the factors underlying differences observed in children's questions and parents' responses in different sociocultural contexts.

The findings also have implications for developing evidence-based resources and programs for parents and children during the pandemic. Based on the findings, it is important to inform parents about the nature of the virus, safety measures, and precautions as children frequently inquire about these topics. It is also essential to provide explanatory information to parents in the COVID-19 related resources. Parents' who feel more knowledgeable and have more explanatory information could nurture children's explanation-seeking questions. 


\section{References}

Ataca, B. (2009). Turkish family structure and functioning. Perspectives on human development, family, and culture, 108-125.

Bates D, Mächler M, Bolker B, Walker S (2015). Fitting linear mixed-effects models using lme4. Journal of Statistical Software, 67(1), 1-48. doi: 10.18637/jss.v067.i01.

Baydar, N., Küntay, A. C., Yagmurlu, B., Aydemir, N., Cankaya, D., Göksen, F., \& Cemalcilar, Z. (2014). "It takes a village" to support the vocabulary development of children with multiple risk factors. Developmental Psychology, 50(4), 1014-1025. https://doi.org/10.1037/a0034785

Blacker, K. A., \& LoBue, V. (2016). Behavioral avoidance of contagion in childhood. Journal of Experimental Child Psychology, 143, 162-170. https://doi.org/10.1016/j.jecp.2015.09.033

Callanan, M., Shirefley, T., Castaneda, C. L., \& Jipson, J. (2019). Young Children's Ideas About Astronomy. Journal of Astronomy \& Earth Sciences Education (JAESE), 6(2), 45-58. https://doi.org/10.19030/jaese.v6i2.10339

Callanan, M., Solis, G., Castañeda, C., \& Jipson, J. (2020). Children’s Question-Asking across Cultural Communities. In Butler, L. P., Ronfard, S., \& Corriveau, K. H. (Eds.). The Questioning Child, The Questioning Child: Insights from Psychology and Education, 7388, Cambridge University Press https://doi.org/10.1017/9781108553803.005

Callanan, M., \& Jipson, J. (2001). Children's developing scientific literacy. Designing for science: Implications from everyday, classroom, and professional settings, 19-43 
Callanan, M. A., \& Oakes, L. M. (1992). Preschoolers' questions and parents' explanations: Causal thinking in everyday activity. Cognitive Development, 7(2), 213-233.

Chouinard, M. M.(2007). Children's questions: A mechanism for cognitive development. Monographs of the Society for Research in Child Development, i-129.

Curtin, J. (2018). lmSupport: Support for linear models. R package version 2.9.13. https://CRAN.R-project.org/package=lmSupport

Evans, G. W. (2004). The environment of childhood poverty. American psychologist, 59(2), 77.

Feldman, S. (2003). Enforcing social conformity: A theory of authoritarianism. Political Psychology, 24(1), 41-74. https://doi.org/10.1111/0162-895x.00316

Fox J, Weisberg S (2019). An R companion to applied regression. Third edition. Sage, Thousand Oaks CA. https://socialsciences.mcmaster.ca/jfox/Books/Companion/.

Frazier, B. N., Gelman, S. A., \& Wellman, H. M. (2009). Preschoolers' search for explanatory information within adult-child conversation. Child Development, 80(6), 1592-1611.

Gauvain, M., \& Munroe, R. L. (2020). Children's questions in social and cultural perspective. In In Butler, L. P., Ronfard, S., \& Corriveau, K. H. (Eds.). The Questioning Child, The Questioning Child: Insights from Psychology and Education, 183-211, Cambridge: Cambridge University Press.

Gauvain, M., Munroe, R. L., \& Beebe, H. (2013). Children's questions in cross-cultural perspective: A four-culture study. Journal of Cross-Cultural Psychology, 44(7), 11481165. 
Gelman, S., \& Raman, L. (2004). A cross-cultural developmental analysis of children's and adults' understanding of illness in South Asia (India) and the United States. Journal of Cognition and Culture, 4(2), 293-317.

Greenfield, P. M., Keller, H., Fuligni, A., \& Maynard, A. (2003). Cultural pathways through universal development. Annual Review of Psychology, 54(1), 461-490. https://doi.org/10.1146/annurev.psych.54.101601.145221

Haber, A. S., Leech, K. A., Benton, D. T., Dashoush, N., \& Corriveau, K. H. (2021). Questions and explanations in the classroom: Examining variation in early childhood teachers' responses to children's scientific questions. Early Childhood Research Quarterly, 57, 121132. https://doi.org/10.1016/j.ecresq.2021.05.008

Harkness, S., Mavridis, C. J., Liu, J. J., \& Super, C. M. (2015). Parental ethnotheories and the development of family relationships in early and middle childhood. In L. A. Jensen (Ed.), The Oxford handbook of human development and culture: An interdisciplinary perspective (pp. 271-291). Oxford University Press. https://doi.org/10.1093/oxfordhb/9780199948550.013.17

Harris, P. L. (2012). Trusting what you're told: How children learn from others. Harvard University Press.

Harris, P. L., \& Koenig, M. A. (2006). Trust in testimony: How children learn about science and religion. Child Development, 77(3), 505-524. https://doi.org/10.1111/j.14678624.2006.00886.x 
Harris, P. L., Koenig, M. A., Corriveau, K. H., \& Jaswal, V. K. (2018). Cognitive foundations of learning from testimony. Annual Review of Psychology, 69(1), 251-273. https://doi.org/10.1146/annurev-psych-122216-011710

Hernandez, I. G., Menendez, D., Seitz, V., Pinto-Pro, I., Zeitler, M. H., \& Rosengren, K. S. (2020). Parent-child conversations of germ and cold weather theories of the common cold in two cultures. https://doi.org/10.31234/osf.io/7j8pb

Hickling, A. K., \& Wellman, H. M. (2001). The emergence of children's causal explanations and theories: Evidence from everyday conversation. Developmental psychology, 37(5), 668.

Jipson, J. L., Labotka, D., Callanan, M. A., \& Gelman, S. A. (2018). How conversations with parents may help children learn to separate the sheep from the goats (and the robots). In M. M. Saylor, \& P. A. Ganea (Eds.). Active Learning from Infancy to Childhood: Social Motivation, Cognition, and Linguistic Mechanisms, pp. 189-212, Springer International Publishing. https://doi.org/10.1007/978-3-319-77182-3_11.

Kağıtçıbaşı, C. (1990). Family and socialization in cross-cultural perspective: A model of change. In J. Berman (Ed.), Cross-cultural perspectives: Nebraska symposium on motivation, 1989 (pp. 135-200). Lincoln, NE: Nebraska University Press.

Kağıtçıbaşı, C. (2005). Autonomy and Relatedness in Cultural Context. Journal of CrossCultural Psychology, 36(4), 403-422. https://doi.org/10.1177/0022022105275959 
Kalish, C. (1997). Preschoolers' understanding of mental and bodily reactions to contamination: What you don't know can hurt you, but cannot sadden you. Developmental psychology, 33(1), 79.

Kurkul, K. E., \& Corriveau, K. H. (2018). Question, explanation, follow-up: A mechanism for learning from others?. Child Development, 89(1), 280-294.

Legare, C. H., Wellman, H. M., \& Gelman, S. A. (2009). Evidence for an explanation advantage in naïve biological reasoning. Cognitive psychology, 58(2), 177-194.

https://doi.org/10.1016/j.cogpsych.2008.06.002

LeVine, R. A., Dixon, S., LeVine, S., Richman, A., Leiderman, P. H., Keefer, C. H., \& Brazelton, T. B. (1994). Child care and culture: Lessons from Africa. Cambridge University Press. https://doi.org/10.1017/CBO9780511720321

LeVine, R. A., LeVine, S., Schnell-Anzola, B., Rowe, M. L., \& Dexter, E. (2011). Literacy and mothering: How women's schooling changes the lives of the world's children. Oxford University Press.

Menendez, D., Klapper, R. E., Golden, M. Z., Mandel, A. R., Nicholas, K. A., Schapfel, M. H., Silsby, O. O., Sowers, K. A., Sumanthiran, D., Welch, V. E., \& Rosengren, K. S. (2021). “When will it be over?” US children's questions and parents' responses about the COVID19 pandemic. PLOS ONE, 16(8), e0256692. https://doi.org/10.1371/journal.pone.0256692

Rogoff, B. (2003). The cultural nature of human development. Oxford University Press.

Ronfard, S., Zambrana, I. M., Hermansen, T. K., \& Kelemen, D. (2018). Question-asking in childhood: A review of the literature and a framework for understanding its development. Developmental Review, 49, 101-120. https://doi.org/10.1016/j.dr.2018.05.002 
Rosengren, K. S., Miller, P. J., Gutierrez, I. T 614 ., Chow, P. I., Schein, S. S., \& Anderson, K. N. Eds.). (2014). Children's understanding of death: Toward a contextualized and integrated account. Monographs of the Society for Research in Child Development, 79, 1141. https://doi. org/10.1111/mono.v79.1

Sunar, D. (2009). Mothers' and fathers' child-rearing practices and self-esteem in three generations of urban Turkish families. Perspectives on human development, family and culture, 126-139.

Tizard, B., \& Hughes, M. (2008). Young children learning. John Wiley \& Sons

Turkish Ministry of Education. (2022). Turkish Ministry of Education. Covid-19. http://covid19.meb.gov.tr/

Turkish Ministry of Health. (2022). Covid-19 Vaccine Information Platform. https://covid19asi.saglik.gov.tr/

Ünlütabak, B., Nicolopoulou, A., \& Aksu-Koç, A. (2019). Questions asked by Turkish preschoolers from middle-SES and low-SES families. Cognitive Development, 52, 100802.

Vygotsky, L. S. (1987). The collected works of L. S. Vygotsky, Vol. 1. Problems of general psychology. (R. W. Rieber \& A. S. Carton, Eds.). Plenum Press.

WHO Coronavirus (COVID-19) Dashboard. (2021). With Vaccination Data. https://covid19.who.int/ 


\section{Supplementary Materials}

\section{Appendix: Coding Schemes as adopted from Menendez et al. (2021)}

\section{Table 1}

\section{Children's Questions}

\begin{tabular}{|c|c|c|}
\hline Code & Definition & Examples \\
\hline 1. Immunology - Virus & $\begin{array}{l}\text { Questions about what the } \\
\text { coronavirus is, how it is } \\
\text { transmitted, what causes } \\
\text { it, and how it is } \\
\text { cured/treated }\end{array}$ & $\begin{array}{l}\text { What is the corona? } \\
\text { Why is it dangerous? } \\
\text { How is it transmitted? } \\
\text { Why did the virus appear? } \\
\text { How many people got sick? } \\
\text { Did they get better? How did they } \\
\text { heal? }\end{array}$ \\
\hline 2. Immunology - Safety & $\begin{array}{l}\text { Questions about how the } \\
\text { virus affects the security } \\
\text { of people and resources }\end{array}$ & $\begin{array}{l}\text { Is the world coming to an end? } \\
\text { Will I get sick too? } \\
\text { Will people die? } \\
\text { When will the virus end? } \\
\text { What is the number of cases? } \\
\text { When will the vaccine come? }\end{array}$ \\
\hline $\begin{array}{l}\text { 3. Adjustment - } \\
\text { Preventative Measures }\end{array}$ & $\begin{array}{l}\text { Questions about the } \\
\text { measures taken to } \\
\text { protect against } \\
\text { coronavirus (mask, } \\
\text { distance, cleaning) }\end{array}$ & $\begin{array}{l}\text { Why do people wear masks? } \\
\text { Why are we washing our hands? } \\
\text { Why do we get vaccinated? }\end{array}$ \\
\hline $\begin{array}{l}\text { 4. Adjustment - } \\
\text { Lifestyle }\end{array}$ & $\begin{array}{l}\text { Questions about } \\
\text { quarantine, curfew } \\
\text { restrictions, age } \\
\text { restrictions imposed by } \\
\text { the state }\end{array}$ & $\begin{array}{l}\text { Why can't we get out? } \\
\text { Why are the shops closed? }\end{array}$ \\
\hline 5. School/Work & $\begin{array}{l}\text { Online lessons, new } \\
\text { normal, questions about } \\
\text { work and school life in } \\
\text { the pandemic }\end{array}$ & $\begin{array}{l}\text { Why don't you go to work? } \\
\text { When will I be able to go to } \\
\text { school? }\end{array}$ \\
\hline $\begin{array}{l}\text { 6. Interpersonal } \\
\text { Interaction }\end{array}$ & $\begin{array}{l}\text { Questions about social } \\
\text { distance, friends, } \\
\text { relatives, and neighbors }\end{array}$ & $\begin{array}{l}\text { When will I see my friends? } \\
\text { Why can't I see my friends? }\end{array}$ \\
\hline 7. Other & $\begin{array}{l}\text { Questions that do not fit } \\
\text { into the above categories }\end{array}$ & $\begin{array}{l}\text { Will we sell our house? } \\
\text { Do we have enough money? }\end{array}$ \\
\hline
\end{tabular}


Table 2

Parents' Responses

\begin{tabular}{|c|c|c|}
\hline Code & Definition & Examples \\
\hline \multicolumn{3}{|l|}{ Mutually exclusive } \\
\hline 1. Authority & $\begin{array}{l}\text { Explanations of parents, } \\
\text { government agencies, religious } \\
\text { structures, or other authority } \\
\text { figures }\end{array}$ & $\begin{array}{l}\text { Q: Will we be sick? } \\
\text { A: If we follow the rules, we } \\
\text { won't be sick. } \\
\text { Q: Can I go out? } \\
\text { A: There is a curfew for children. }\end{array}$ \\
\hline 2. No Explanation & $\begin{array}{l}\text { Answers given by parents } \\
\text { without any explanation }\end{array}$ & $\begin{array}{l}\text { Q: Is the virus dangerous? } \\
\text { A: Yes } \\
Q: \text { When will the disease end? } \\
\text { A: I don't know }\end{array}$ \\
\hline $\begin{array}{l}\text { 3. Realistic } \\
\text { Explanation }\end{array}$ & $\begin{array}{l}\text { Scientific, medical, or common } \\
\text { sense explanations by parents }\end{array}$ & $\begin{array}{l}\text { Q: Why can't I see viruses? } \\
\text { A: Viruses are so small that we } \\
\text { cannot see them with our eyes. } \\
Q: \text { Why is there a quarantine? } \\
\text { A: To prevent the disease from } \\
\text { spreading. }\end{array}$ \\
\hline $\begin{array}{l}\text { 4. Supernatural } \\
\text { Explanation }\end{array}$ & $\begin{array}{l}\text { Statements made by parents by } \\
\text { employing supernatural powers } \\
\text { or using personification }\end{array}$ & $\begin{array}{l}\text { Q: Will the disease ever end? } \\
\text { A: Don't worry, the virus will get } \\
\text { tired of making people sick. }\end{array}$ \\
\hline 5. Other & $\begin{array}{l}\text { Comments that do not fall into } \\
\text { the listed categories above }\end{array}$ & $\begin{array}{l}\text { Q: Are we not going to school? } \\
\text { A: We can play games } \\
Q: \text { Why don't you go to work? } \\
\text { A: Study your lesson. }\end{array}$ \\
\hline \multicolumn{3}{|c|}{ Non-mutually exclusive } \\
\hline 1. Reassurance & $\begin{array}{l}\text { Explanations made by parents } \\
\text { to calm and comfort their } \\
\text { children }\end{array}$ & $\begin{array}{l}\text { Q: Will we be sick? } \\
\text { A: Don't worry, nothing will } \\
\text { happen to us. } \\
\text { Q: What if we get a virus? } \\
\text { A: The virus cannot harm us. }\end{array}$ \\
\hline $\begin{array}{l}\text { 2. Religious } \\
\text { concepts }\end{array}$ & $\begin{array}{l}\text { Explanations made by parents } \\
\text { to calm and comfort their } \\
\text { children }\end{array}$ & $\begin{array}{l}\text { Q: Will I be sick too? } \\
\text { A: No, God bless us. } \\
Q: \text { When will it end? } \\
\text { A: Let's pray to God for it to end. }\end{array}$ \\
\hline
\end{tabular}


Table 3

Child Questions and Parent Responses

\begin{tabular}{|c|c|c|}
\hline Code & Definition & Examples \\
\hline \multicolumn{3}{|l|}{ Question } \\
\hline Elicits Explanation & $\begin{array}{l}\text { It is scored according to } \\
\text { whether the child's question } \\
\text { requires an explanation }(1) \\
\text { or not }(0) \text {. }\end{array}$ & $\begin{array}{l}\text { Why do we get sick? (1) } \\
\text { Will I be able to go to } \\
\text { school? (0) }\end{array}$ \\
\hline \multicolumn{3}{|l|}{ Answer } \\
\hline Declaration & $\begin{array}{l}\text { It is coded according to } \\
\text { whether the answer given } \\
\text { by the parent is composed } \\
\text { of one-worded and short } \\
\text { expressions. }\end{array}$ & $\begin{array}{l}\text { Q: Will I get sick if I take off } \\
\text { my mask? } \\
\text { A: Yes. (1) } \\
\text { A: You may be sick because } \\
\text { viruses can be transmitted } \\
\text { through the respiratory } \\
\text { tract. (0) }\end{array}$ \\
\hline \multicolumn{3}{|c|}{ Match Between Question and Answer } \\
\hline Evades & $\begin{array}{l}\text { The parent evades the } \\
\text { child's question. }\end{array}$ & $\begin{array}{l}\text { Q: If I get coronavirus, will } \\
\text { I die? } \\
\text { A: Please don't speak like } \\
\text { that. }\end{array}$ \\
\hline Evades and Elaborates & $\begin{array}{l}\text { The parent evades the } \\
\text { question and makes a } \\
\text { detailed explanation on } \\
\text { another subject. }\end{array}$ & $\begin{array}{l}\text { Q: When will we go to the } \\
\text { park? } \\
\text { A: There are many ways we } \\
\text { can have fun at home, we } \\
\text { can do puzzles, for example. }\end{array}$ \\
\hline Answers & $\begin{array}{l}\text { The parent answers the } \\
\text { child's question. }\end{array}$ & $\begin{array}{l}\text { Q: Is the virus dangerous? } \\
\text { A: Yes, it is very dangerous. }\end{array}$ \\
\hline
\end{tabular}




\section{Table 4}

Parents' responses to why questions

\begin{tabular}{|c|c|c|}
\hline Code & Definition & Examples \\
\hline 1. Authority & $\begin{array}{l}\text { Reference to (1) the } \\
\text { authority of parents }(2) \text {, } \\
\text { official institutions (3), } \\
\text { religious structures, or } \\
\text { (4) other authority } \\
\text { figures }\end{array}$ & $\begin{array}{l}\text { Q: Why can't we go to the park? } \\
\text { A: We will not go to the park. } \\
\text { Q: Why can't we go out? } \\
\text { A: If we break the rules, the police will write } \\
\text { fines. }\end{array}$ \\
\hline 2. Supernatural & $\begin{array}{l}\text { Statements made by } \\
\text { parents by employing } \\
\text { supernatural powers }\end{array}$ & $\begin{array}{l}\text { Q: Why can't we go out? } \\
\text { A: The monsters will be angry with us if you } \\
\text { go out on the street. }\end{array}$ \\
\hline 3. Covid-19 & $\begin{array}{l}\text { Parents' responses } \\
\text { directly (1) or indirect } \\
\text { (2) related to Covid-19 }\end{array}$ & $\begin{array}{l}\text { Q: Why do we need to use hand sanitizer? } \\
\text { A: We use hand sanitizer to kill germs. } \\
\text { Q: Why can't we go out? } \\
\text { A: The virus spreads in crowded } \\
\text { environments. }\end{array}$ \\
\hline 4. Self-Protection & $\begin{array}{l}\text { Parents' answers that } \\
\text { include the safety of } \\
\text { their children (1), their } \\
\text { families (2), or both ( } 3 \text { ) }\end{array}$ & $\begin{array}{l}\text { Q: Why can't we go to the park? } \\
\text { A: If we go to the park, you can get a virus } \\
\text { from there. } \\
\text { Q: Why do we need to wash our hands? } \\
\text { A: We have to be careful for a while not to be } \\
\text { sick. }\end{array}$ \\
\hline $\begin{array}{l}\text { 5. Contradicting } \\
\text { Social Norms }\end{array}$ & $\begin{array}{l}\text { Answers showing } \\
\text { violation of social } \\
\text { norms formed during } \\
\text { the Covid-19 period }\end{array}$ & $\begin{array}{l}\text { Q: Why do we need to use hand sanitizer? } \\
\text { A: You don't have to use hand sanitizer. } \\
\text { Q: Why can't we go out? } \\
\text { A: We can go out. }\end{array}$ \\
\hline $\begin{array}{l}\text { 6. Social } \\
\text { Responsibility }\end{array}$ & $\begin{array}{l}\text { Answers showing care } \\
\text { about other people's } \\
\text { health }\end{array}$ & $\begin{array}{l}\text { Q: Why do we need to use hand sanitizer? } \\
\text { A: We should wear a mask to avoid making } \\
\text { other people sick. } \\
\text { Q: Why can't we go to the park? } \\
\text { A: To reduce the spread of the virus. }\end{array}$ \\
\hline 7. Other & $\begin{array}{l}\text { Answers that do not fall } \\
\text { into any category }\end{array}$ & $\begin{array}{l}\text { Q: Why do we need to wash our hands? } \\
\text { A: You should always be careful. } \\
\text { Q: Why do we need to use hand sanitizer? } \\
\text { A: Don't waste your disinfectant. }\end{array}$ \\
\hline
\end{tabular}




\begin{tabular}{|l|l|l|} 
8. Repeating & $\begin{array}{l}\text { Same explanations } \\
\text { given by parents to } \\
\text { multiple questions }\end{array}$ & \\
\hline
\end{tabular}

Table 5

Parents' responses about any changes in questions

\begin{tabular}{|c|c|c|}
\hline Code & Definition & Examples \\
\hline \multicolumn{3}{|l|}{ No Change } \\
\hline 1. No & $\begin{array}{l}\text { Parents' answers stating that } \\
\text { they did not see any change } \\
\text { in children's questions }\end{array}$ & No, I didn't see any change \\
\hline \multicolumn{3}{|l|}{ Change } \\
\hline 2. Health & $\begin{array}{l}\text { Answers stating that the } \\
\text { questions of children } \\
\text { include health, biology, or } \\
\text { life issues }\end{array}$ & $\begin{array}{l}\text { She asks questions about } \\
\text { how to be healthier. } \\
\text { He started asking how the } \\
\text { vaccine worked. }\end{array}$ \\
\hline 3. Safety & $\begin{array}{l}\text { Answers stating that } \\
\text { children include the safety } \\
\text { of their families, friends, or } \\
\text { themselves in their } \\
\text { questions }\end{array}$ & $\begin{array}{l}\text { He keeps asking if anything } \\
\text { will happen to us if we get } \\
\text { the virus. } \\
\text { She asks if she is sick when } \\
\text { she coughs. }\end{array}$ \\
\hline $\begin{array}{l}\text { 4. Lifestyle Changes and } \\
\text { Preventative Measures }\end{array}$ & $\begin{array}{l}\text { Answers stating that the } \\
\text { children's questions include } \\
\text { the changes due to the } \\
\text { pandemic or the } \\
\text { preventative measures } \\
\text { taken. }\end{array}$ & $\begin{array}{l}\text { She keeps asking when to } \\
\text { stop wearing masks. } \\
\text { He asks if he will meet with } \\
\text { his friends again. }\end{array}$ \\
\hline $\begin{array}{l}\text { 5. Changes in the number } \\
\text { of questions }\end{array}$ & $\begin{array}{l}\text { Answers indicating that the } \\
\text { questions of children have } \\
\text { increased or decreased }\end{array}$ & $\begin{array}{l}\text { Asking more and more } \\
\text { questions now. } \\
\text { Since he learned a lot from } \\
T V \text {, he doesn't ask as many } \\
\text { questions as before. }\end{array}$ \\
\hline 6. Other & $\begin{array}{l}\text { Answers that do not fall into } \\
\text { any category }\end{array}$ & $\begin{array}{l}\text { She's very sensitive now. } \\
\text { Tired of the coronavirus. }\end{array}$ \\
\hline
\end{tabular}


Table 6

Parents' responses about coping strategies

\begin{tabular}{|c|c|c|}
\hline Code & Definition & Examples \\
\hline 1. No strategies & $\begin{array}{l}\text { Answers stating that parents } \\
\text { don't have any strategies }\end{array}$ & $\begin{array}{l}\text { We don't have time for strategy } \\
\text { I can't think of anything }\end{array}$ \\
\hline $\begin{array}{l}\text { 2. Acting like } \\
\text { nothing } \\
\text { happened }\end{array}$ & $\begin{array}{l}\text { Answers stating that parents } \\
\text { ignore the Covid-19 } \\
\text { outbreak. }\end{array}$ & We act like everything is normal \\
\hline $\begin{array}{l}\text { 3. Treat like a } \\
\text { vacation }\end{array}$ & $\begin{array}{l}\text { Answers stating that parents } \\
\text { consider this process like a } \\
\text { vacation }\end{array}$ & We act like we're on vacation early. \\
\hline $\begin{array}{l}4 . \\
\text { Prayer/Mosque }\end{array}$ & $\begin{array}{l}\text { Answers showing that } \\
\text { parents engage in religious } \\
\text { activities such as prayer }\end{array}$ & We pray \\
\hline $\begin{array}{l}\text {. Keep a } \\
\text { schedule/regular } \\
\text { routine }\end{array}$ & $\begin{array}{l}\text { Answers showing that } \\
\text { parents cope by establishing } \\
\text { a regular routine }\end{array}$ & $\begin{array}{l}\text { We get up at the same time every } \\
\text { morning. } \\
\text { Everybody is doing their job as usual, } \\
\text { eating lunch together }\end{array}$ \\
\hline 6. Covid related & $\begin{array}{l}\text { Parents' direct or indirect } \\
\text { coping strategies related to } \\
\text { Covid-19 }\end{array}$ & $\begin{array}{l}\text { We stay at home } \\
\text { We take care of our health } \\
\text { We share our problems and talk } \\
\text { We are washing our hands } \\
\text { We watch/avoid news about Covid-19 } \\
\text { We pay attention to social distance } \\
\text { We focus on the things that relax us } \\
\text { We try to stay positive }\end{array}$ \\
\hline 7. Activities & $\begin{array}{l}\text { Replies stating that parents } \\
\text { engage in different activities } \\
\text { together as a family }\end{array}$ & $\begin{array}{l}\text { We play games at home } \\
\text { We watch } T V \text { and movies } \\
\text { We do sports. We go for a walk } \\
\text { We cook, We read a book }\end{array}$ \\
\hline $\begin{array}{l}\text { 8. Social } \\
\text { interaction }\end{array}$ & $\begin{array}{l}\text { Answers that parents say } \\
\text { they cope through social } \\
\text { interaction }\end{array}$ & $\begin{array}{l}\text { We walk together } \\
\text { We play games as a family } \\
\text { Meeting with people via Zoom } \\
\text { We use social media }\end{array}$ \\
\hline 9. Education & $\begin{array}{l}\text { Answers related to the } \\
\text { education of children }\end{array}$ & $\begin{array}{l}\text { Homeschooling } \\
\text { Online education continues/EBA }\end{array}$ \\
\hline 10. Other & & $\begin{array}{l}\text { Strategies not included in the above } \\
\text { categories }\end{array}$ \\
\hline
\end{tabular}

